\title{
Die verpleegdiensbestuurders binne die Suid-Afrikaanse Militêre gesondheidsdiens se persepsies oor hul vlak van motivering
}

\author{
A Fischer, Magisterstudent, Departement Verpleegkunde, RAU \\ Marie Muller, D. Cur., Professor, Department Verpleegkunde, RAU
}

\section{The perceptions of nursing service managers, within the South African Military Health Service, on their level of motivation}

\section{Uittreksel}

Die proses van transformasie in die Suid-Afrikaanse Militêre Gesondheidsdienste het ' $n$ invloed op die verpleegdiensbestuurders se vlak van motivering. Die doel met hierdie studie was om die verpleegdiensbestuurders, werksaam in die Suid-Afrikaanse Militêre Gesondheidsdienste, se persepsies oor hul vlak van motivering by wyse van ' $n$ kwalitatiewe navorsingsontwerp te verken en te beskryf. Fokusgroeponderhoudvoering is as data-insamelingsmetode gebruik en die getranskribeerde onderhoude is vervolgens aan ' $\mathrm{n}$ inhoudsontleding onderwerp. ' $n$ Totaal van vier onderhoude is met 33 verpleegdiensbestuurders landswyd gevoer. Die resultate toon dat hul vlak van motivering laag is. Die resultate is in twee hooftemas verdeel, naamlik demotiveerders en motiveerders. Hierdie resultate is aan die hand van Herzberg se motiveringsteorie ontleed. Daar word aanbeveel dat ' $n$ motiveringstrategie ontwikkel word, gebaseer op Herzberg se motiveringsteorie en op die Hackman-Oldham taakverrykingsmodel.

\section{Abstract}

The process of transformation in the South African Military Health Services, has influenced the nursing service managers' level of motivation and the following research question is applicable: what are the perceptions of the nursing service managers within the South African Military Health Services on their level of motivation? The purpose with this study was to explore and describe the perceptions of nursing service managers on their level of motivation within these health services. A qualitative research design was utilized and four focus group interviews were conducted with 33 nursing service managers country wide. The transcribed interviews were exposed to a content analysis. The results confirm that the level of motivation amongst these nursing service managers is low. The demotivators relate mainly to the following: inadequate acknowledgement, job insecurity in relation to the future, problems with the process of integration, transformation and rationalization, problems with management, many labour related issues, poor/inadequate communication, inadequate support, increased work load, poor physical environment, negative publicity and poor self motivation. Although there were a few motivators identified, they were of less importance. These results were interpreted within Herzberg's motivation theory to identify the hygiene/maintenance factors and to assess whether the important motivators were in place. During any process of change, and/or when the level of motivation amongst employees is low, it is important to adequately manage the environment (hygiene/maintenance factors within the Herzberg theory). But it is even more important to ensure that the motivators are in place or to intensify them. It is therefore recommended that a motivation strategy, based on the Herzberg theory as well as the Hackman-Oldham job enrichment model, be developed, implemented and evaluated.

\section{Inleiding}

Die totstandkoming van die Suid-Afrikaanse Nasionale Weermag (SANW) op 27 April 1994 het beteken dat die weermagte van die voormalige TBVC state, die voormalige Suid-Afrikaanse Weermag (SAW), sowel as lede van die "Azanian Peoples' Liberation Army" (APLA) en "Umkhonto We Sizwe" (MK) tot " $\mathrm{M}$ nuwe geïntegreerde weermag saamgesnoer moes word. Die proses waardeur die nuwe Weermag daargestel/getransformeer word, behels dat alle dienende lede eers geïntegreer sal word in die SANW. Daarna sal die Weermag ' $n$ proses van transformasie/omvorming deurloop. Tydens transformasie/omvorming is daar indringend gekyk na die nuwe rol wat die Weermag moet speel en die magsontwerp sal volgens die rolvoorskrifte geskied. Om te voldoen aan die eise van ' $n$ verkleinde, getransformeerde Weermag, is die laaste stap die rasionalisasie van ongeveer 20000 lede om die verlangde magsterkte te verkry (ANON:1994). 
Voor en tydens die integrasieproses is lede van die SAW voortdurend verseker dat hulle regverdig behandel sou word en dat standaarde en disssipline gehandhaaf sou word. Alhoewel die "British Military Advisory and Training Team" (BMATT) die integrasie- en transformasieproses moniteer, bestaan die persepsie by lede van die voormalige SAW dat hulle nie regverdig behandel word nie. Hierdie persepsie is onder andere geskep deur die aanstelling van voormalige MK en APLA lede in senior posisies, die toename in dissiplinêre verhore en die integrasie van voormalige TBVC lede met behoud van salarisse wat aansienlik hoër is as diè van die voormalige SAW lede. Die Suid Afrikaanse Militêre Gesondheidsdiens (SAMGD) vorm 'n integrale deel van die SANW. Die veranderinge binne die SANW die afgelope vyf jaar het " $"$ direkte invloed op die SAMGD en sy lede, asook op die verpleegkundiges uitgeoefen. Dit blyk dat daar " $n$ gebrek aan motivering by die verpleegdiensbestuurders binne die SAMGD bestaan. Die vraag ontstaan dus: wat is die verpleegdiensbestuurders se persepsies oor hul vlak van motivering? Die doel met die navorsing is om die verpleegdiensbestuurders se persepsies ten opsigte van hul vlak van motivering binne die konteks van die SAMGD te verken en te beskryf. Hierdie resultate sal as basis gebruik word vir die formulering van ' $n$ motiveringstrategie, aan die hand van Herzberg (1968) se motiveringsteorie en die Hackman-Oldham-taakverrykingsmodel (Hackman, Oldham, Janson, Purdy \& Walters, 1974) vir die verpleegdiensbestuurders werksaam in die Suid-Afrikaanse Militêre Gesondheidsdiens. Hierdie artikel fokus op die persepsies van die verpleegdiensbestuurders oor hul vlak van motivering en die motiveringstrategie sal in ' $n$ opvolgartikel weergee word.

Alhoewel daar beide interne en eksterne faktore is wat die verpleegdiensbestuurder binne die SAMGD se vlak van motivering beïnvloed, fokus hierdie navorsing hoofsaaklik op die eksterne faktore en derhalwe aanvaar die navorser Herzberg (1968/76) en Hackman et al. se teoretiese aannames oor motivering en die bestuur van eksterne faktore om die verpleegdiensbestuurder se vlak van motivering te verbeter. Dit is dus nie net belangrik om die eksterne omgewingsfaktore (higiëne/instandhoudingsfaktore) effektief te bestuur nie, maar die ontwikkeling en implementering van ' $n$ taakverrykingsprogram is ook nodig ten einde die verpleegdiensbestuurders se vlak van motivering te verbeter.

\section{Terminologie}

\section{Verpleegdienshestuurder}

Die verpleegdiensbestuurder is ' $n$ geregistreerde verpleegkundige/vroedvrou wat ' $n$ bestuurpos in die SAMGD beklee.

\section{Persepsie}

' $n$ Persepsie is die verpleegdiensbestuurder binne die SAMGD se beskouing/waarneming oor ' $n$ bepaalde verskynsel, naamlik, hul vlak van motivering in die werkplek tydens die proses van transformasie/omvorming in die SAMGD.

\section{Motivering}

Motivering is ' $n$ houding wat die gedrag van die verpleegdiensbestuurder in die werksopset verantwoord:
"Motivation at work is an attitude that justifies the behavior that arises when people are given a combination of ability to do a good job and the opportunity to have a good job. The attitude of motivation impels people to seek appropriate arenas where their ability can be enhanced by the opportunity to put it in use, in the expectation that there will be further development of the ability" (Herzberg, 1976: '99).

\section{Motiveringstrategie}

'n Program wat gemik is op higiëne verbetering (Herzberg, 1968/76) en taakverryking onder verpleegdiensbestuurders werksaam in die SAMGD ten einde hul vlak van motivering te verbeter.

\section{Navorsingsontwerp}

' $n$ Kwalitatiewe, beskrywende navorsingsontwerp is binne die Militêre Gesondheidsdiens-konteks uitgevoer. Inligting ten opsigte van die verpleegdiensbestuurders se persepsies is ingesamel deur middel van fokusgroeponderhoude gebaseer op die beginsels soos beskryf deur Krueger (1994:11 - 19). Daar is gebruik gemaak van die dienste van ' $n$ fasiliteerder om die onderhoude te voer. Die populasie bestaan uit ' $n$ totaal van 63 verpleegdiensbestuurders landwyd. ' $n$ Totaal van vier fokusgroepe met 33 deelnemers is landwyd gehou, gebaseer op die beginsels van doelgerigte steekproefneming soos beskryf deur Burns en Grove (1993:246). Die eerste fokusgroeponderhoud is as " $n$ loodsstudie gebruik. Aangesien geen veranderinge in die vrae en aard van die onderhoudvoering aangebring is nie, is die resultate van hierdie fokusonderhoud benut. Verteenwoordiging is verseker deur die vier grootste militêre instellings in te sluit. Die volgende vrae is tydens die fokusgroeponderhoude in Afrikaans en Engels gestel: "Wat is u persepsies (siening/ beskouing) ten opsigte van die vlak van motivering onder verpleegdiensbestuurders in die Suid-Afrikaanse Militêre Gesondheidsdiens?" Die onderhoude is op oudioband vasgelê en later deur ' $n$ onafhanklike persoon verbatim getranskribeer. Inhoudsontleding is uitgevoer volgens die beginsels soos beskryf deur Tesch (1990: 142-145). Die resultate is vervolgens aan die hand van Herzberg (1968/1976) se teorie geïnterpreteer waar die motiveerders en higiëne/ instandhoudingsfaktore geïdentifiseer is. Hierdie resultate is tydens ' $n$ opvolgdebat aan die deelnemers vir bevestiging voorgelê en hulle is versoek om 'n prioriteitswaarde aan elke tema toe te ken. Die vertrouenswaardigheid van die studie is verseker deur Lincoln en Guba (1985:301-305) se beginsels na te volg:

- Verlengde betrokkenheid: die navorser is reeds sedert 1987 'n verpleegdiensbestuurder en het verskeie bestuursposisies binne die SAMGD beklee wat deurlopende skakeling met verpleegdiensbestuurders in die praktyk verseker. Die navorser is bekend met die probleme en frustrasies van die verpleegdiensbestuurders binne hierdie werkskonteks. Sy is ook vertroud met die Weermagkultuur waarbinne die verpleegdiensbestuurders funksioneer.

- Die benutting van ' $n$ verskeidenheid databronne en lidkontrole vir die verifiëring van die resultate en die toekenning van prioriteitswaardes aan temas.

- 'n Onafhanklike en vaardige onderhoudvoerder is vir al die fokusgroeponderhoudvoering benut.

- Veldnotas is tydens die onderhoudvoering deur ' $n$ 
Tabel 1:Faktore wat ' $n$ negatiewe effek het op die motivering van die verpleegdiensbestuurders binn die SAMGD

\begin{tabular}{|l|c|c|c|c|c|c|c|c|c|}
\hline \multirow{2}{*}{$\begin{array}{c}\text { HOOFTEMAS en Fokusgroep- } \\
\text { frekwensie (N=4) }\end{array}$} & \multicolumn{5}{c|}{ Prioriteitswaardes } & \multicolumn{3}{c|}{$\begin{array}{c}\text { Individuele frekwensie } \\
\text { (N=33) }\end{array}$} \\
\cline { 2 - 10 } & $\begin{array}{l}\text { Loodsgp } \\
(\mathrm{N}=8)\end{array}$ & $\begin{array}{c}\text { Gp1 } \\
(\mathrm{N}=9)\end{array}$ & $\begin{array}{c}\text { Gp2 } \\
(\mathrm{N}=8)\end{array}$ & $\begin{array}{l}\text { Gp3 } \\
(\mathrm{N}=8)\end{array}$ & $\begin{array}{l}\text { Loodsgp } \\
(\mathrm{N}=8)\end{array}$ & $\begin{array}{l}\text { Gp1 } \\
(\mathrm{N}=9)\end{array}$ & $\begin{array}{l}\text { Gp2 } \\
(\mathrm{N}=8)\end{array}$ & $\begin{array}{l}\text { Gp3 } \\
\text { (N=8) }\end{array}$ \\
\hline Gebrek aan erkenning & 4 & 4 & 1 & 1 & 1 & 12 & 6 & 14 & 1 \\
\hline $\begin{array}{l}\text { Onsekerheid by personeel oor } \\
\text { toekoms }\end{array}$ & 4 & 7 & 6 & 8 & 4 & 3 & 4 & 2 & 1 \\
\hline $\begin{array}{l}\text { Probleme rondom integrasie, } \\
\text { transformasie \& rasionalisasie }\end{array}$ & 3 & 2 & 2 & 5 & 0 & 16 & 17 & 4 & 0 \\
\hline Probleme met bestuur & 3 & 1 & 4 & 2 & 0 & 4 & 2 & 3 & 0 \\
\hline $\begin{array}{l}\text { Probleme rondom arbeids- } \\
\text { verhoudinge }\end{array}$ & 3 & 3 & 3 & 4 & 0 & 8 & 5 & 3 & 0 \\
\hline $\begin{array}{l}\text { Swak/gebrekkige } \\
\text { kommunikasie }\end{array}$ & 3 & 5 & 0 & 3 & 3 & 1 & 0 & 6 & 1 \\
\hline Gebrek aan ondersteuning & 2 & 6 & 0 & 7 & 0 & 2 & 0 & 7 & 0 \\
\hline Verhoogde werklas & 1 & 0 & 5 & 0 & 0 & 0 & 4 & 0 & 0 \\
\hline Swak fisiese omgewing & 1 & 0 & 7 & 0 & 0 & 0 & 2 & 0 & 0 \\
\hline $\begin{array}{l}\text { Negatiewe publisiteit vir die } \\
\text { SANW }\end{array}$ & 1 & 0 & 8 & 0 & 0 & 0 & 4 & 0 & 0 \\
\hline Gebrek aan selfmotivering & 1 & 0 & 0 & 0 & 2 & 0 & 0 & 0 & 2 \\
\hline
\end{tabular}

onafhanklike navorser afgeneem om die dinamika tydens die onderhoude vas te lê.

- Na afloop van elke onderhoud het die navorser en onderhoudvoerder ' $n$ konsultasiesessie gehou om buitengewonde faktore te identifiseer wat moontlike sydigheid in die data-insamelingsproses kon meebring.

- Die resultate is met die deelnemers bevestig en konsensus is bereik betreffende die klassifisering en die prioriteitsbepaling van die resultate.

- Die beginsels van ' $n$ digtheidsbeskrywing van die navorsingsontwerp is nagevolg en "n ouditspoor is gehou vir eksterne ouditering.

Die etiese standaarde vir navorsing soos beskryf deur DENOSA (1998) is nagevolg om die gehalte van die navorsing te verbeter. Skriftelike toestemming om die navorsing te onderneem is verkry vanaf die bevelstruktuur van die SAMGD op Hoofkwartiervlak, sowel as van die Afdeling Inligting van die SANW. Daarna is skriftelike toestemming by die onderskeie Bevelvoerders van hospitaal en Mediese Kommandemente verkry $(\mathrm{N}=4)$. Laastens is skriftelike toestemming vanaf elke individuele deelnemer $\quad(\mathrm{N}=33)$ verkry. Die versekering is ook gegee dat die inligting as streng vertroulik hanteer sal word, alhoewel die SAMGD as nasionale instelling geïdentifiseer is. Die dienste van ' $n$ kliniese sielkundige en maatskaplike werker is verkry en is aan die onderskeie deelnemers na afloop van elke fokusgroeponderhoud aangebied indien dit nodig sou wees.

\section{Resultate}

Die verpleegdiensbestuurders se persepsies is in twee hooftemas, tewete die motiveerders en demotiveerders ingedeel. Die demotiveringsfaktore word in tabel een uiteengesit en binne Herzberg (1968/76) se teoretiese raamwerk (sien tabel twee) in die derde tabel geïnterpreteer. Die motiveerders met betrekking tot die werk self en die higiëne-faktore met betrekking tot die werksomgewing, is vergelyk. In tabel een word die demotiveerders uiteengesit en die fokusgroepfrekwensie weergegee, 'n prioriteitswaarde is aan elke faktor toegeken en individuele frekwensies $(\mathrm{N}=33)$ word ook aangetoon. Die fokusgroepfrekwensie verwys na die aantal groepe waarbinne ' $n$ bepaalde tema ter sprake gekom het. Die "N" waarde verwys na die aantal groepe wat betrokke was en waarbinne die temas ter sprake is. Die prioritieitswaardes toon aan watter belangrikheidwaarde elke groep aan ' $n$ bepaalde tema (demotiveerders) tydens die opvolgdebat toegeken het. Die " $N$ ' waarde onder elke groep toon die aantal deelnemers in die fokusgroeponderhoud aan 
Die individuele frekwensie toon die aantal kere aan wat daar binne " $n$ bepaalde groep na ' $n$ bepaalde tema verwys is.

Verpleegdiensbestuurders is van mening dat die vlak van motivering laag is: "It is the worse it's ever been." "Jy vra die verkeerde persoon - daar is hoegenaamd niks wat my in hierdie plek motiveer nie." Daar is egter nie konsensus tussen die groepe oor die prioriteitswaardes wat aan elke demotiveerder toegeken is nie. Die resultate word voorts onder die demotiveerders en motiveerders weergegee.

\section{Demotiveerders}

Die faktore wat ' $\mathrm{n}$ negatiewe effek op die motivering van verpleegdiensbestuurders in die SAMGD het, word in tabel 1 uiteengesit en wentel hoofsaaklik rondom ' $\mathrm{n}$ gebrek aan erkenning, probleme rondom integrasic, transformasie en rasionalisasie, probleme met bestuur en rondom die beginsels van arbeidsverhoudinge, swak/gebrekkige kommunikasie, onsekerheid oor die toekoms, gebrek aan ondersteuning, verhoogde werklas, swak fisiese omgewing, negatiewe publisiteit vir die weermag en ' $n$ gebrek aan kennis en selfmotivering. Slegs die faktore wat " $n$ hoë prioriteitswaarde gekry het, word kortliks uitgelig

\section{Gebrek aan erkenning}

Hierdie tema is binne al vier groepe bespreek. Drie van die groepe het dit "n prioriteitswaarde van "l" gegee. Die loodsgroep het " $n$ prioriteitswaarde van " 4 " toegeken, maar dit kan nogtans as " $n$ belangrike tema beskou word. Daar is baie dikwels binne die onderskeie groepe na hierdie tema verwys (sien tabel een). "Ons kry geen erkenning nie." "Daar is net nie erkenning nie." "Ek wil daarby voeg - geen erkenning nie." "Al is jy militêr-gekwalifiseerd - in verpleging bly die rangstruktuur maar nog dieselfde wat dit al die jare was." "Op hierdie stadium is daar geen voordeel vir ons nie - ons kry nie dieselfde salaris as ons eweknieë nie, al is jy militêr opgelei." "Daar is nou geen bevorderingsmoontlikhede vir ons nie." "Die verpleegkundiges - veral die wat artikel 38A moet doen - kry nie genoeg erkenning nie." "Hulle doen die werk van 'n dokter en kry geen erkenning daarvoor nie." Dit blyk dus dat die verpleegkundige nie dieselfde erkenning as ander werknemers geniet nie en dit lei tot demotivering. Die erkenning van prestasies word deur Herzberg (1968) as ' $n$ belangrike motiveerder beskou (sien tabel twee).

\section{Probleme rondom integrasie, transformasie en rasionalisasie}

Hierdie tema het in slegs drie van die groepe ter sprake gekom, maar twee van die groepe het dit "n prioriteitswaarde van " 2 " gegee. Daar is 16, 17 en vier keer onderskeidelik binne die betrokke drie groepe oor hierdie tema gepraat. Enkele direkte aanhalings word ter stawing gegee: "Ja, dit kan eintlik twee kante toe gaan. Regstellend boontoe, en regstellend ondertoe wat nie vaardig is nie. En die regstelling ondertoe het ' $n$ baie groot impak omdat die standaarde verlaag en die las op die paar mense wat wil en kan, word al hoe meer en hulle kyk in die verpleegdiensbestuurder se oë. Waanheen moet sy kyk?" "Integrasie hou nou aan vir vier jaar, transformasie hou nou aan vir drie jaar. Jy hoor net al die "rumours" en niemand weet meer wat, waar en hoe nie." "Ek voel ons het nog nie die kultuurverskille oorbrug nie en om daarmee saam te werk en te verstaan - dit is moeilik." "Daar is nog baie konflik oor rasseverskille." "The major problem is the insecurities which are arising from the integration process ... this is reflected in the high rate of turnover." "Die rassekonflik ..." "There is still a colour problem" "Die inkonsekwentheid waarmee standaarde toegepas word." Dit blyk dus dat die proses van integrasie, transformasie/rasionalisasie nie altyd positief beskou word nie en as ' $n$ belangrike demotiveerder dien. Die werk self, asook die werksomstandighede, is ' $\mathrm{n}$ higiëne faktor (Herzberg, 1968) wat in die motiveringstrategie aangespreek moet word.

\section{Probleme rondom arbeidsverhoudinge}

Slegs drie van die groepe het hierdie tema aangespreek, maar prioriteitswaardes van " 3,3 en 4" onderskeidelik is toegeken. Hierdie tema is ook dikwels te berde gebring binne die drie tersaaklike groepe. "Die mense wat nie Staandemag is nie behoort aan vakbonde wat vir hulle beding en ons het niemand wat vir ons beding nie;" "Jy kom in "n situasie waar jy " $n$ toesighouer moet wees oor "n skoonmaker wat " $n$ vakbond het en die vakbond stoomroller jou." "Ja, hulle intimideer jou as " $n$ enkeling wat nie ondersteun word nie." "Jy kan nie meer "n ondergeskikte dissiplineer nie." "Hulle (vakbonde) bly inmeng in ons lynfunksie." "Die vlak van motivering word beslis beïnvloed deur die feit dat daar dubbele standaarde is tussen persone wat poste kry deur regstellende aksie en persone wat wel in die weermag is." "Daar is ook "n gebrek aan kennis oor arbeidverhoudinge." "Die inkonsekwente toepassing van dissipline ..." Die proses van transformasie het dus " $n$ negatiewe impak op arbeidsverhoudinge en dien derhalwe as 'n demotiveerder. Interpersoonlike verhoudinge, status, toesighouding en aspekte wat die persoonlike lewe van ' $n$ werknemer raak, is belangrike higiëne faktore (sien tabel

\section{Tabel 2: Uiteensetting van Herzberg (1968) se teorie}

\begin{tabular}{|l|l|}
\hline $\begin{array}{l}\text { MOTIVEERDERS } \\
\text { mbt die werk self }\end{array}$ & $\begin{array}{l}\text { HIGIENE FAKTORE } \\
\text { mbt tot die omgewing }\end{array}$ \\
\hline Prestasie & $\begin{array}{l}\text { Maatskappybeleid en } \\
\text { administrasie }\end{array}$ \\
\hline Erkenning van prestasies & Toesighouding \\
\hline Werk self & Salaris \\
\hline Verantwoordelikheid & $\begin{array}{l}\text { Interpersoonlike ver- } \\
\text { houdingsmet portuur- } \\
\text { groep, ondergeskiktes en } \\
\text { meerderes }\end{array}$ \\
\hline Bevordering & Status \\
\hline Moontlikheid van groei & Werksekerheid \\
\hline & $\begin{array}{l}\text { Fisiese werksomstandig- } \\
\text { hede en byvoordele }\end{array}$ \\
\cline { 2 - 2 } & Persoonlike lewe \\
\hline
\end{tabular}


Tabel 3: Indeling van resultate volgens Herzberg (1976) se teorie

\begin{tabular}{|l|l|}
\hline INSTANDHOUDINGSFAKTORE & MOTIVERINGSFAKTORE \\
\hline Onsekerheid by personeel tov toekoms & Gebrek aan erkenning van prestasies \\
\hline Probleme mbt integrasie, transformasie en rasionalisasie & Verhoogde werkslas \\
\hline Probleme met topbestuur & \multirow{2}{*}{ Gebrek aan kennis } \\
\hline Probleme rondom arbeidsverhoudinge & \\
\cline { 1 - 1 } Swak/gebrekkige kommunikasie & \\
\cline { 1 - 1 } Gebrek aan ondersteuning & \\
\cline { 1 - 1 } Swak fisiese omgewing & \\
\cline { 1 - 1 } Negatiewe publisiteit vir die SANW & \\
\cline { 1 - 1 } Tekort aan hulpbronne & \\
\cline { 1 - 2 } Beperkings van die ondergeskiktes & \\
\hline
\end{tabular}

twee) wat dus aangespreek moet word om die verpleegdiensbestuurder se motiveringsvlak positief te beïnvloed.

\section{Probleme met bestuur}

Drie van die groepe het hierdie tema aangespreek en waardes van onderskeidelik "1, 4 en 2" toegeken. " ... die feit dat ons net krisisbestuur van die oggend tot die aand toepas, maak nie saak watter beplanning daar op die tafel is nie, dit is net krisisbestuur." "Dit gaan oor topbestuur ondersteun nie die middelvlak nie." "Besluite word deur topbestuur geneem ..." "Mens kry half die gevoel hulle weet nie ..." "We are excluded from major decisions that affect us as nurses directly" "Jy is ook net "n boodskapper - jy mag nie self besluit nie." "Beleid is onduidelik of ontoepaslik" "Daar is rompslomp en adminstratiewe 'red tape'..." Dit blyk dus dat die verpleegdiensbestuurders nie as mede-bestuurders erken word nie. Die rol van bestuur in ' $n$ organisasie is ' $n$ belangrike instandhoudingsfaktor (sien tabel drie) wat ' $n$ impak op motivering kan hê.

\section{Swak/gebrekkige kommunikasie}

Drie groepe het hierdie tema bespreek en waardes van onderskeidelik " 3 en 5" is as prioriteite toegeken. "Besluite wat topbestuur neem word nie deur gekommunikeer na onder toe nie." "... hulle weet iets wat ons nie weet nie en ... daarom dat hulle nie vir ons wil sê nie." "They don't let us know in time." "Die oomblik wanneer jy terugvoer verlang van iemand - vat dit " $n$ geweldige lang tydperk en jy moet twee, drie keer vra vir terugvoer." "Ek dink daar is " algemene gevoel van negatiwiteit en moedeloosheid wat eintlik vir my gaan oor onsekerheid wat mens direk in verband bring met "n gebrek aan kommunikasie." "Jy kry net nooit ordentlike terugvoer nie en dit is nie net in die direktoraat waar die terugvoer swak is nie." "Lack of effective communication between the nursing service managers and their sub- ordinates." Ontoereikende kommunikasie met topbestuur dien dus as ' $n$ demotiveerder en behoort as " $n$ instandhoudingsfaktor aandag te geniet ten einde die vlak van motivering onder verpleegdiensbestuurders te verbeter.

\section{Onsekerheid by personeel oor die toekoms}

Alhoewel al vier die groepe hierdie tema bespreek het, is ' $n$ relatief lae prioritietswaarde aan hierdie tema toegeken. Die volgende direkte aanhalings is tersaaklik: "Topstruktuur vat pakkette - wat weet hulle wat ons nie weet nie?" "Wat is die toekoms van die Weermag?" "Baie van hierdie ouens ... het ons uitverkoop." "I feel we don't get a clear picture - it feels as if they are hiding things from you; and also there are problem areas that they say they give attention to but nothing is happening ... why?" "Jy kan nie loopbaanbeplanning doen nie - daar is nie poste beskikbaar nie." "Hulle weet hulle sal nooit nou by die rangstruktuur uitkom nie." "We lack info on the future." Die verpleegdiensbestuurders is dus onseker oor die toekoms en dit dien as ' $n$ demotiveerder. Die fasilitering van werksekerheid as ' $n$ eksterne instandhoudingsfaktor, behoort dringend aandag in ' $n$ motiveringstrategie te geniet.

\section{Gebrek aan ondersteuning}

Twee groepe het hierdie tema bespreek en prioritieitswaardes van onderskeidelik 6 en 7 daaraan toegeken. "Dit gaan oor topbestuur ondersteun nie die middelvlak nie." "Ons kry geen ondersteuning nie." "We are not supported by our senior members." "Ons het net geen ondersteuningsdiens nie." Dit blyk dat beide fisiese ondersteuningsdienste en psigiese ondersteuning vanaf topbestuur problematies is. Fisiese omstandighede is ' $n$ prominente higiëne faktor en " $n$ gebrek aan ondersteuning behoort ook as " $n$ instandhoudingsfaktor aangespreek te word. 


\section{Verhoogde werkslas, swak fisiese omgewing en negatiewe publisitieit vir die SANW}

Hierdie drie faktore is net deur een groep elk bespreek en lae prioritietswaardes van " 5,7 en 8 " is onderskeidelik aan die temas toegeken. "Die feit dat verpleegkundiges moet instaan vir ander beroepsgroepe as hulle "n tekort aan personeel het." "Dan word die verpleegkundiges ingespan en moet hulle take doen - die nie-verpleegtake." "So word hulle oorlaai met ander take sodat hulle nie by hulle primêre taak uitkom nie." "Dinge gaan agteruit en die werk word net mèer." "Die saalsuster is nie gemotiveer nie agv die geweldige werkslas ..." "Vieruur, wanneer die werk nog moet voortgaan - is die een groep nie bereid om verder aan te gaan (agv vervoerprobleme) met werk wat nog nie voltooi is nie en die blanke lid moet dan net eenvoudig aangaan om die werk te voltooi." "Daar is nie genoeg fasiliteite in die enkelkwartiere nie - dit is nie meer wat dit was nie." "As jy aanvra vir "n stetoskoop dan is daar nie geld nie." "Ek voel deesdae skaam om " $n$ Weermag-uniform te dra - ek praat van buitekant. Daar is negatiewe publisiteit van buite af." Dit is duidelik dat die verpleegdiensbestuurders demotivering beleef as gevolg van finansiële en psigo-sosiale veranderinge. Die toereikende bestuur van hierdie instandhoudingsfaktore is dus belangrik.

\section{Motiveerders}

Die motiveringsfaktore sentreer rondom voordele/geleenthede, inherente motivering, kollegiale ondersteuning, werksbevrediging, beskikbaarheid van bronne, goeje beeld van die SANW en geloof in die toekoms. Hierdie resultate word nie in tabelvorm weergegee nie - die demotiveerders het meer aandag in die onderhoudvoering geniet.

\section{Voordele/geleenthede}

Dit blyk dat die werk by die SAMGD uitdagend beskou word. Daar is in al vier die fokusgroepe melding gemaak van die voordele en geleenthede by die weermag wat as ' $n$ motiveerder dien: “... dan is jy biejtie soldaat en dan doen jy ' $n$ computerkursus ... Daar is baie geleenthede." "Die weermag bied vir jou baie geleenthede - ek gebruik die weermag vir sport en ek kom op baie plekke waar ek andersins nooit sou gekom het nie." "Die medies is ook "n groot voordeel." "Die voordele wat ek kry is goed - soos my studies wat vir my betaal word, kursusse wat ek kan bywoon en vry medies." Die intensifisering van hierdie aspekte behoort in die motiveringstrategie dus meer aandag te geniet.

\section{Kollegiale ondersteuning}

Hierdie tema is deur twee groepe gemeld: "Die ondersteuning onder mekaar is goed." "Vir my is die motivering, "n mens se kollegas, wat nog probeer help om hierdie sinkende skip bo te hou." Positiewe kollegiale ondersteuning is dus belangrik om as " $n$ instandhoudings/higiëne faktor in die motiveringstrategie aan te spreek.

\section{Werksbevrediging}

Twee groepe was van mening dat werksbevrediging ' $n$ belangrike motiveerder is. "Ek hou van my werk." "Vir my is elke dag ' $n$ motivering en elke dag is " $n$ uitdaging - ek hou daarvan." Dit is dus belangrik om die gehalte van werkslewe of werksbevrediging onder werknemers te fasiliteer om hul vlak van motivering positief te beïnvloed.

\section{Beskikbaarheid van bronne}

Groep drie was van mening dat die weermag se bronne as motiveerder dien. "The availability of resources is important." Alhoewel sommige deelnemers 'n tekort aan bronne beleef het (vergelyk demotiveerders), is daar tog ander wat van mening is dat die bronne toereikend is.

\section{Goeie beeld van die SANW}

Hierdie aspek is as motiveerder deur een groep vermeld: "Die goeie beeld van die weermag - hulle sien op na die militêre verpleegkundige." Hierdie beskouing is teenstrydig met die beskouing van sommige deelnemers wat weer van mening is dat die Weermag se beeld tans negatief is soos reeds bespreek onder demotiveerders.

\section{Stadiger tempo}

Een groep was van mening dat die stadiger tempo voordelig is. "Die pas is stadiger - ek hou van Afrikatyd. Jy hoef nie so te jaag om alles klaar te kry nie." Die tempo waarteen werk uitgevoer word kan ook dus " $n$ impak op motivering hê.

\section{Interpretasie volgens Herzberg se motiveringsteorie}

Herzberg (1968) het 'n teorie ontwikkel gebaseer op die aanname dat mense twee stelle behoeftes het, naamlik om pyn wat in die omgewing ontstaan te vermy en ' $n$ behoefte om sielkundig deur middel van werk te groei. Volgens hierdie teorie is daar sekere faktore wat dien as bepalers van werkstevredenheid, naamlik prestasie, erkenning van prestasie, die moontlikheid van groei, die werk self, verantwoordelikheid en bevordering. Laasgenoemde drie is die belangrikste faktore wat ' $n$ blywende houdingsverandering teweegbring (Herzberg, 1968:73). Wanneer mense ontevrede is met hul werk vind hulle fout met die omgewing. Omdat die faktore wat werksontevredenheid veroorsaak essensieel die omgewing beskryf en primêr moet voorkom dat ontevredenheid met die werk ontstaan, word hulle die higiëne faktore genoem. (In Herzberg se latere werk (1976) word hulle die instandhoudingsfaktore genoem). Herzberg se teorie word in tabel twee uitgebeeld. Volgens die Herzberg-teorie ondervind mense werkstevredenheid indien die motiveerders wat hy geidentifiseer het teenwoordig is en toegepas word in 'n werksituasie. Die motiveerders dra by tot persoonlike ontwikkeling en self-verryking by die werknemer. Indien die instandhoudingsfaktore (higiëne faktore) binne 'n werksituasie positief is, dien dit slegs om die omgewing vir die werknemer aanvaarbaar te maak. Dit motiveer die werknemer dus nie om harder te werk nie. Die motiveerders moet dus by wyse van takkverryking versterk word. 


\section{Taakverryking as 'n strategie om die vlak van motivering te verhoog}

Aangesien die navorsingsresultate aantoon dat daar ' $n$ gebrek aan motivering onder verpleegdiensbestuurders in die SAMGD bestaan, is dit nodig om maatreëls in werking te stel om die gebrek aan motivering om te keer, ten einde te verseker dat verpleegdiensbestuurders produktief is en " $n$ hoë vlak van gehalte-werklewe ervaar. Gebaseer op die werk van Herzberg (1968/76) het Hackman et al. (1974) 'n model vir taakverryking ontwikkel. Deur middel van takverryking word die werknemer se vlak van interne motivering verhoog omdat die werk as sinvol en betekenisvol ervaar word. Volgens Hackman et al. (1974) is daar sekere konsepte wat geïmplementeer moet word, kernelemente van 'n taak wat aangespreek moet word en 'n kritiese sielkundige ingesteldheid van die werknemer moet ontwikkel word, om positiewe motiveringsresultate op persoonlike en werksvlak te fasiliteer (sien figuur een). Hierdie model kan dus positief aangewend word om die demotiveerders wat in hierdie navorsing geïdentifiseer is se effek, naamlik die verlaging van instandhoudings/higiëne en motiveringsfaktore, te neutraliseer. Dit impliseer die ontwikkeling van 'n motiveringstrategie (deur die toepaslike rolspelers), bestaande uit strategieë om higiëne verbetering en taakverryking teweeg te bring. Die doel met hierdie motiveringstrategie is die verhoging van die verpleegdiensbestuurders se vlak van motivering ten einde doelbereiking binne die konteks van die SAMGD te bewerkstellig of te fasiliteer. Hackman et al. (1974) se model word in figuur een voorgestel.

'n Motiveringstrategie sal ontwikkel word wat Herzberg (1768/76) en Hackman et al. (1974) se beginsels integreer, gebaseer op die resultate van hierdie navorsing om die verpleegdiensbestuurders werksaam in die SAMGD se vlak van motivering te verhoog.

\section{Gevolgtrekkings en aanbevelings}

Uit die navorsing is dit duidelik dat die vlak van motivering onder verpleegdiensbestuurders in die SAMGD laag is. Faktore wat verantwoordelik is vir hierdie toedrag van sake is geidentifiseer en volgens Herzberg se klassifikasie ingedeel in instandhoudingsfaktore en motiveringsfaktore. Regstelling van die instandhoudingsfaktore is belangrik, maar dit sal nie 'n wesenlike effek hê op hul vlak van motivering nie. Die regstel van die omgewing om dit aanvaarbaar te mak vir die werknemer is belangrik, aangesien dit tot gevolg het dat die werknemer op haar/sy taak kan konsentreer en haar/hom nie oor gebreke in sy omgewing hoef te bekommer nie.

Die volgende samevattende stellings word gestel:

- die verpleegdiensbestuurders werksaam by die SAMGD se vlak van motivering is laag;

- daar is beide instandhoudings- en motiveringsfaktore wat negatief is;

- die instandhoudingsfaktore hou verband met onsekerheid by personeel oor hul toekoms, probleem met integrasie, transformasie, rasionalisasie, probleme met topbestuur en arbeidsverhoudings, swak kommunikasie, swak fisiese omgewing, negatiewe publisiteit, 'n tekort aan hulpbronne en beperkings van ondergeskiktes;

- die motiveringsfaktore hou verband met die gebrek aan erkenning van prestasies, 'n verhoogde werklas en 'n gebrek aan kennis by die verpleegdiensbestuurders oor die proses van transformasie.

Die volgende aanbevelings word gemaak:

- die ontwerp, implementering en evaluering van ' $n$ motiverinstrategie (higiëne verbeterings- en taakverrykingsprogram) vir die verpleegdiensbestuurders werksaam in die SAMGD om die demotiverende dimensies teë te werk; - $\quad$ die ontwikkeling van 'n model vir die motivering van verpleegdiensbestuurders tydens die proses van transformasie/ omvorming;

- $\quad$ 'n evaluering van die impak van 'n motiveringstrategie op die gehalte van verpleging, produktiwiteit, vlak van werksbevrediging / ervaring van gehalte-werklewe op die verpleegdiensbestuurder werksaam in die SAMGD.

\section{Slotopmerkings}

Dit is belangrik om die vlak van motivering onder verpleegdiensbestuurders op ' $n$ positiewe/hoë vlak te handhaaf. Die verpleegdiensbestuurder as leier, het 'n betekenisvolle invloed op die funksionering, produktiwiteit, ingesteldheid en vlak van motivering op die verpleegpersoneel in ' $n$ verpleegdiens. Die motiveringsfaktore wat in hierdie navorsing as gebrekking geidentifiseer is, moet reggestel word deur middel van takverryking. Sodra die verantwoordelikhede/pligte van die verpleegdiensbestuurder meer uitdagend gemaak word met die nodige erkenning vir die bevredigende afhandeling van verantwoordelikhede/pligte, behoort die motivering van die groep te verbeter. Dit is egter ook belangrik dat die beginsels van veranderingsbestuur tydens ' $n$ proses van transformasie/omvorming toegepas moet word. 


\section{Verwysings}

ANON 1994: Belangrike beslissings ivm die stigting van die SA Nasionale Weermag (SANW). HSANW Interne Kommunikasiebulletin, No 33, 24 April 1994.

BURNS N \& GROVE SK 1993: The practice of nursing research. Conduct, critique and utilization. Philadelphia: WB Saunders.

DEMOCRATIC NURSING ORGANIZATION OF SOUTH AFRICA 1998: Position paper: Ethical standards for nurse researchers.

HACKMAN JR; OLDHAM G; JASON R; PURDY K \& WALTERS RW 1974: New strategy for job enrichment. Yale University: School of organization and management.

HERZBERG F 1968: Work and the nature of man. London: Granada Publishing Ltd.

HERZBERG F 1976: The managerial choice. To be effective and to be human. Illinois: Dow Jones-Irwan.

KRUEGER RA 1994: Focus groups. A practical guide for applied research. London: SAGE.

LINCOLN YS \& GUBA, EG 1985: Naturalistic inquiry. London: SAGE.

TESCH R 1990: Qualitative research: Analysis types and software tools. Hampshire: Falmer Press. 